\title{
Comparison of tax bonus as a tool of tax benefit for taxpayers in V4 countries and Austria
}

\author{
Renata Stanley ${ }^{1, *}$, and Zuzana Kubascikova ${ }^{1}$ \\ ${ }^{1}$ University of Economics in Bratislava, Faculty of Business Informatics, Department of Accounting \\ and Auditing, Dolnozemska 1, 85235 Bratislava, Slovakia
}

\begin{abstract}
Research background: Tax legislation provides taxpayers some advantages which enable them to reduce their tax base in the tax statement. The amount of the tax advantage varies depending on the state and also the tax policy of the country. The tax bonus is one of the benefits, which can affect the amount of net income of taxpayers. The state's efforts to mitigate the effects of covid-19 are currently even greater in order to sustain the functioning operations of taxpayers and at the same time to start the growth of economies again. All countries neighbouring Slovakia provide tax bonuses in certain amounts or other benefits for supporting families. The issue of tax bonuses is not given much attention by authors in the Slovak Republic or at the international level. So far, there is no article that deals with a comprehensive comparison of the tax bonus in several countries.

Purpose of the article: The aim of this paper is to present and characterize the tax benefits provided to taxpayers by the tax legislation of the Slovak Republic and subsequent comparison with similar tax benefits provided by the Visegrad countries and neighbouring Austria.

Methods: The method used the most in the paper are analysis and comparison.

Findings \& Value added: The contribution of this article is a comprehensive overview and comparison of the rules for the application of the tax bonus among the V4 countries and Austria and an evaluation of the most advantageous system among these countries in 2021.
\end{abstract}

Keywords: tax bonus; tax base; taxpayer

JEL Classification: $H 21 ; H 24 ; K 34$

\footnotetext{
*Corresponding author: renata.stanley@euba.sk
} 


\section{Introduction}

Child benefits or tax bonuses for children can be considered tools that serve policy objectives which have subsequent benefits for children (Cho, 2017). In different countries may vary the name used for the tax benefit. For example the Czech legislation uses term of „tax relief" for a maintained child corresponding to Slovak tax bonus (Paliderova et al., 2015).

The concept of tax bonus was used for the first time in the Slovak Republic in 2003, replacing the previous non-taxable part of the tax base for a dependent child. Since then, the tax bonus has been changed several times. Among the most significant are the changes made in 2021, when the amount of the tax bonus for different categories was changed up to 2 times (Lenartova, 2015).

The tax bonus is one of the tax benefits offered to individuals by the tax system of the Slovak Republic. The tax bonus can be claimed by a taxpayer as a taxpayer for each dependent child living in the same household with the taxpayer. The condition for claiming the tax bonus is that only one of the parents in a joint household is always entitled to the tax bonus.

If the taxpayer becomes entitled to the tax bonus, the tax legislation provides two ways of paying the tax bonus. The first way is to be paid by the employer monthly on top of the employee's salary and the second way is to be paid through the tax office once a year after the tax return has been filed.

As of 1 January 2021, the amount of the tax bonus has been set at EUR 23.22 per month if the dependent child has reached the age of 6 and EUR 46.44 if the dependent child has not reached the age of 6 . As of 1 July 2021, a new category for a child aged 6 to 15 came into force, where the amount of the tax bonus is EUR 39.47 (Act no. 311/2001 Coll. Labor Code as amended).

Table 1. Amount of the monthly tax bonus in the Slovak Republic in 2021

\begin{tabular}{|l|c|}
\hline \multicolumn{2}{|l|}{ Monthly amount of tax bonus per child from 1.1.2021 to 30.6.2021 } \\
\hline under 6 years & 46.44 \\
\hline over 6 years & 23.22 \\
\hline Monthly amount of tax bonus per child from 1.7.2021 \\
\hline under 6 years & 46.44 \\
\hline over 6 years to 15 years & 39.47 \\
\hline over 15 years & 23.22 \\
\hline
\end{tabular}

Source: Own processing on the basis of legislation

Entitlement to the tax bonus is regulated by Section 33 of Act No. 595/2003 Coll. on Income Tax, as amended. One of the main conditions under which a taxpayer as an individual is entitled to a tax bonus is that in the relevant tax period he or she has earned taxable income pursuant to Section 5 and Section 6 (1) and (2) of at least 6 times the established minimum wage for the relevant tax period. In 2021, the minimum wage was set at EUR 623. It follows from the preceding text that the taxpayer must have taxable income for the relevant tax period of at least EUR 3,738 (Act no. 311/2001 Coll. Labor Code as amended).

Topic of tax bonus was processed also within the countries of OECD. The fiscalization of child benefits means a shift to the use of the tax system, especially the income tax, to support families with children instead of direct public benefits. In some countries, this fiscalization has occurred under the influence of social policies promoting work for welfare (OECD, 2010). 


\section{Methodology and data}

For the purposes of this article, we have drawn data mainly from the laws of individual countries and internet sources relating to the issue of the tax bonus in the current period of 2021.

In our research we used mainly methods of analysis and comparison. In the case of the tax bonus, we focused on the analysis of tax benefits provided by the current tax legislation in the Slovak Republic. We approach the amounts of the tax bonus and the conditions of entitlement to the tax bonus. We then analyse the tax benefits provided by the tax legislation of the Czech Republic, Austria, Poland and Hungary.

The results of the analysis will then be collated into a summary example, comparing which tax legislation provides the highest amount of tax bonus and thus the highest reduction of the tax base.

For the purposes of converting foreign currencies into euro currency, we base our calculation on the ECB exchange rate valid at the beginning of this year, exactly as of 4 January 2021. The individual foreign currency exchange rates needed for the purposes of this article are as follows:

for the Czech currency, EUR 1 = CZK 26.14,

for the Polish currency, EUR 1 = PLN 4,55

for the Hungarian currency, EUR $1=$ HUF 361,32

\section{Results}

\subsection{Tax Bonus in Czech Republic}

The Czech tax system, similarly to the Slovak one, offers its taxpayers various tax benefits. One of such tax benefits, which is regulated by Act no. 586/1992 Sb. Czech National Council on Income Tax as amended, is a tax credit for a dependent child who lives with the taxpayer in one household. In addition to tax legislation, Czech authors (Jahoda and Godarová, 2012) and (Vostatek, 2016) also deal with the issue of tax benefits in their articles.

The first condition by which a taxpayer is entitled to claim a tax bonus is that the taxpayer must be a tax resident of the Czech Republic. The right to apply the tax bonus also applies to tax non-residents under the condition of achieving $90 \%$ of income from sources in the Czech Republic from the total income that the taxpayer achieved in the tax period, which applies similarly to all other countries surveyed .

Another condition for entitlement to the tax bonus is the amount of income that the taxpayer achieved in the tax period. The tax bonus for a dependent child is entitled to be claimed by the taxpayer whose taxable income from dependent activity and business in the tax period exceeded at least 6 times the minimum wage. The minimum wage in 2021 in the Czech Republic is set at CZK 15,200 (EUR 581.48). The amounts are converted at the exchange rate of the ECB and the sum of the taxpayer's income for the tax period should exceed CZK 91,200 (EUR 3,488.91).

In Czech republic was a change in the amount of the tax benefit as of 1 July 2021 also, but here in the form of an increase in the tax benefit to 2 or more children. However, at the time of writing, we did not have the data available, and in calculating the case studies we based ourselves on the legislative framework in force on 30 June 2021.

The taxpayer is entitled to a tax bonus of :

CZK 15,204 (EUR 581.62) per year per child.

CZK 19,404 (EUR 742.28) for the second child and 
CZK 24,204 (EUR 925.90) for the third child and any other dependent child living in the same household as the taxpayer.

\subsection{Tax Bonus in Poland}

Polish legislation, in Act of July 26, 1991 on personal income tax, provides entitled to reduce the amount of the tax base if the taxpayer in the monitored calendar year, undertake the care of a dependent child, he worked as a legal representative of a dependent child who lived with the taxpayer in the household or carry out foster care by a court decision or decision of the local authority. According to Polish tax legislation, both tax residents and non-tax residents are entitled to a reduction in the tax base.

The application of the reduction of the amount of the tax base for taxpayers is carried out every month of the calendar year, if the taxpayer in the given calendar year provided care for a dependent child living with the taxpayer in the same household. Polish tax legislation regulates the conditions for the maximum amount of taxable income for claiming a reduction in the amount of the tax base. If the taxpayer lives in a household with wife / husband, a condition of claiming to reduce the amount of the tax base is the amount of taxable income spouse not exceeding 112000 PLN (24 615.38 EUR) amounts are translated at the exchange rate of the ECB. If the taxpayer cares for a dependent child as a single or divorced parent or widower, the condition for claiming a reduction in the amount of the tax base is not to exceed the amount of taxable income of PLN 56,000 (EUR 12,307.69) for the relevant tax period.

The amount by which the taxpayer reduces his tax base depends on the number of dependent children living in the same household as the taxpayer as follows:

- $\quad$ PLN 92.67 (EUR 20.37) per month - for the first and second dependent child

- $\quad$ PLN 166.67 (EUR 36.63) per month - for the third dependent child

- $\quad$ PLN 225 (49.45 Eur) per month - for the fourth and every other dependent child

\subsection{Tax Bonus in Austria}

Austrian tax legislation, in particular the Federal Law of 7 July 1988 on personal income taxation EStG 1988, offers its taxpayers various tax advantages in the form of various types of tax bonuses for dependent children.

In 2020, Austria introduced the calculation of the amount of entitlement to the tax bonus based on the country's standard of living. The country's standard of living is published regularly by the European Union, which is used by Austria to calculate the reduction coefficient for family allowances and tax bonuses if dependent children do not reside in Austria. The amount of the tax bonus in Austria in 2021 was set at EUR 58.40 per month for each dependent child living with the taxpayer in the same household.

In 2019, Austria introduced new tax benefits granted to its taxpayers. This is a tax bonus for Familienbonus Plus families . Every taxpayer who has been paid family allowances for each dependent child living in the same household as the taxpayer is entitled to the tax bonus in the relevant tax period. Unlike in the Slovak Republic, both spouses are entitled to claim the tax bonus, while each spouse is entitled to claim half of the tax bonus. The amount of the Familienbonus Plus tax bonus is divided into Austrian tax legislation into two categories according to the child's age:

- up to the age of 18 ,

- $\quad$ after the age of 18 .

In the first case, where a dependent child living in the same household as the taxpayer has not reached the age of 18 in the relevant tax period, the amount of the tax bonus is EUR 125 per month or EUR 1,500 per year. 
In the second case, when the dependent child has reached the age of 18 in the tax period, the amount of the Familienbonus Plus tax bonus will be EUR 41.68 per month and EUR 500 per year.

Taxpayers have another option to reduce the tax base for each dependent child through the Alleinverdienerer tax bonus. The condition for entitlement to this type of tax bonus is that all taxable income in the relevant tax period does not exceed the amount of EUR 6,000 .

Austrian tax legislation also refers to taxpayers who themselves raise a dependent child living in the same household as the taxpayer. The Allenerzieher tax bonus is intended for single parents and breadwinners such as single and divorced mothers and fathers and widows.

\subsection{Tax Bonus in Hungary}

In Law Act CXVII 1995 on tax personal income it is this form of tax credit described as a family discount.

Taxpayers who are entitled to family allowances for a child raised in the same household as the taxpayer are entitled to the application of the tax bonus for a dependent child in the territory of Hungary. Entitlement to the tax bonus arises on the 91st day of pregnancy. A dependent child is considered to be a child until the end of compulsory school attendance. After completing compulsory schooling, a dependent child is reclassified as a dependent until the age of 23 , if he or she is studying at a secondary school or university and is preparing for a future profession.

A taxpayer who is entitled to a tax bonus in the form of a family rebate is regulated by the Personal Income Tax Act in the amount of this tax bonus as follows (amounts in EUR are converted at the ECB exchange rate:

- $\quad$ One child living in the same household - HUF 10,000 (EUR 27.68)

- $\quad$ Two children living in the same household - HUF 20,000 (EUR 55.35)

- $\quad$ Three or more children living in the same household - 33,000HUF (EUR 91.33)

If two taxpayers are caring for a dependent child or children in the same household, the Hungarian Personal Income Tax Act allows them to distribute the amount of the tax bonus between the two taxpayers. Each of the taxpayers has the opportunity to determine the amount of tax bonus they want to claim. If one of the taxpayers is not entitled to claim a tax bonus, the other taxpayer will provide him with a part of the amount of the tax bonus which he does not claim.

\subsection{Tax Bonus Applied to Case Studies}

In the following example, we will illustrate the amounts of tax bonuses for a dependent child to which individuals are entitled in the countries we have selected. For the calculation, we will use a uniform amount of taxable income, which flowed only from dependent activity. In the calculation, we will take into account two variants, where one child will live in the same household with the taxpayer in the first variant and in the second variant we will be based on the data that three children live in the same household with our taxpayer. In the following calculation, we will abstract from other options to reduce the tax base, to reduce the tax base we will use only the tax bonus for a dependent child.

In the first Option A, we will assume that the natural person for whom the income tax is calculated did not reach the amount of income more than EUR 6,000 in 2021. To simplify the calculation of the contribution burden and focus on the nature, we will start from a single amount of income tax. in the amount of EUR 1,000. The taxpayer, together with his wife, raises one dependent child aged 2 in the same household, to whom he claims 
the tax bonus in full. In our example, the individual person decided to claim the tax bonus once in the tax return. In countries where the main currency is other than the euro, the amounts are converted at the exchange rate of the ECB.

In the following Table 2, we calculate the amount of the tax base reduction based on the data we have determined.

Table 2 Calculation of the amount of the yearly tax bonus Variant A in EUR

\begin{tabular}{|c|c|c|c|c|c|}
\cline { 2 - 6 } \multicolumn{1}{c|}{} & $\begin{array}{c}\text { Slovak } \\
\text { republic }\end{array}$ & $\begin{array}{c}\text { Czech } \\
\text { Republic }\end{array}$ & Austria & Poland & Hungary \\
\hline Income tax & 1,000 & 1,000 & 1,000 & 1,000 & 1,000 \\
\hline Tax bonus & 557.28 & 581.62 & $\begin{array}{c}(700.80+1500 \\
+494) \\
2,694.80\end{array}$ & 244.44 & 332.16 \\
\hline $\begin{array}{c}\text { Income tax } \\
\text { after reduction }\end{array}$ & $\mathbf{4 4 2 . 7 2}$ & $\mathbf{4 1 8 . 3 8}$ & $\mathbf{- 1 , 6 9 4 . 8 0}$ & $\mathbf{7 5 5 . 5 6}$ & $\mathbf{6 6 7 . 8 4}$ \\
\hline
\end{tabular}

Source: Own processing

As we can see in Table 2, each of the selected countries provides different amounts of tax bonus amounts. In our example, the highest amount of the tax bonus can be claimed by a natural person living and working in Austria. It follows that a natural person working in Austria will, in our example, be entitled to a tax refund of EUR 1 694.80, as the amount of tax benefits for the child and family is higher than the amount to be paid by the taxpayer for income tax. This is due to the fact that natural persons working in Austria are entitled to several types of tax bonuses. In our example, an individual was entitled to a classic tax bonus of EUR 700.80 and also Familienbonus Plus to a dependent child living in the same household in the amount of EUR 1,500. As the natural person did not earn more than EUR 6,000 in 2021, the natural person is entitled to the Allenverdienerer tax bonus of EUR 494. Other countries also offer other family benefits and allowances, but they are not part of the same package as in Austria and there are always several criteria and conditions that must be met in order to be paid, unlike Austria, where they are paid automatically, therefore are shown in this case study. If we did not list them here, the net amount of the tax bonus would be only EUR 700.80, which would still be the highest amount of the tax bonus among the monitored countries.

On the contrary, the highest income tax after reduction in our example will be for a taxpayer working in Poland in the amount of EUR 755.56. This is due to the fact that the amount of the tax bonus increases in proportion to the number of children living in the same household as a taxpayer and increases more significantly for up to three children.

In the case of the Slovak Republic, a taxpayer will be entitled to twice the amount of the tax bonus, as the child has not reached the age of 6 . In our case, a taxpayer working in the Slovak Republic will have a reduced income tax in the amount of EUR 442.72.

In the case of the Czech Republic, as in Poland, the amount of the tax bonus depends on the number of children living in the same household as a taxpayer. As in our case one dependent child lives with a taxpayer, the amount of the tax bonus will be 581.62 euros. The amount of the reduced income tax in our case would be EUR 418.38.

In the case of Hungary, the amount of the tax bonus, as in previous cases, depends on the number of children living in the same household. In our case, the amount of the tax bonus will be EUR 332.16 and the amount of the income tax after reduction will be EUR 667.84. 
In the second Option B, in 2021 a physical person earned a taxable income from dependent activity of EUR 24,000. To simplify the calculation, we use a uniform basis for calculating income tax in the amount of EUR 5,000. The taxpayer living in the same household three children aged 1,12,17 years for claiming the tax credit in full and that once a year in a tax return. As in the first case, we will count on a single currency for each country, which is converted at the exchange rate of the ECB as mentioned above.

In the following Table 3, we calculate the amount of the tax base reduction based on the data we have determined.

Table 3 Calculation of the amount of the yearly tax bonus Variant B in EUR

\begin{tabular}{|c|c|c|c|c|c|}
\hline & $\begin{array}{c}\text { Slovak } \\
\text { republic }\end{array}$ & $\begin{array}{c}\text { Czech } \\
\text { Republic }\end{array}$ & Austria & Poland & Hungary \\
\hline $\begin{array}{l}\text { Income } \\
\operatorname{tax}\end{array}$ & 5,000 & 5,000 & 5,000 & 5,000 & 5,000 \\
\hline Tax bonus & $\begin{array}{c}278.64 \\
+ \\
473,64 \\
+ \\
557.28 \\
(\mathbf{1 , 3 0 9 . 5 6 )}\end{array}$ & $\begin{array}{c}581.62 \\
+ \\
742.28 \\
+ \\
925.92 \\
\mathbf{( 2 , 2 4 9 . 8 2 )}\end{array}$ & $\begin{array}{c}700.80 \\
+ \\
700.80 \\
+ \\
700.80 \\
+ \\
1,500 \\
+ \\
1,500 \\
+ \\
1500 \\
(\mathbf{6 , 6 0 2 . 4 0})\end{array}$ & $\begin{array}{c}244.44 \\
+ \\
244.44 \\
+ \\
439.56 \\
\mathbf{( 9 2 8 . 4 4 )}\end{array}$ & $\begin{array}{c}332.16 \\
+ \\
664.20 \\
+ \\
1,095.96 \\
\mathbf{( 2 , 0 9 2 . 3 2 )}\end{array}$ \\
\hline $\begin{array}{l}\text { Income } \\
\text { tax after } \\
\text { reduction }\end{array}$ & $3,690.44$ & $2,750.18$ & $-1,602.40$ & $4,071.56$ & $2,907.68$ \\
\hline
\end{tabular}

Source: Own processing

As in the first case, in variant $\mathrm{B}$, a physical person working and living with children in the territory of Austria, entitled EUR 6,602.40, is entitled to the highest amount of the tax bonus. Unlike in the first case, a natural person working in Austria is not entitled to the Allenverdienerer tax bonus, since the amount of his taxable income in 2021 was more than EUR 6000 . As the natural person was entitled to a higher amount of the tax bonus than his tax liability, he can claim a tax refund of EUR 1,602.40.

On the other hand, as in the first case, a taxpayer working in Poland in the amount of EUR 928.44 is entitled to the lowest amount of the tax bonus. The amount of the reduced income tax in the case of a taxpayer working in the territory of Poland is EUR 4,071.56.

In the case of a taxpayer working in the territory of the Slovak Republic with three children, the amount of the tax bonus will be EUR 1,309.56. The reduced income tax was EUR 3,690.44.

In the case of a taxpayer working in the Czech Republic, the amount of the tax bonus increased in proportion to each child living in the same household. In our case, the amount of the tax bonus was EUR 2,249.82 and the amount of the reduced income tax was EUR $2,750.18$.

In the case of a taxpayer working in Hungary with three children in the same household, the amount of the tax bonus was EUR 2,092.33 and, in our case, the amount of the reduced income tax was EUR 2,907.68. 


\section{Conclusion}

Each of the analyzed tax legislations provides its taxpayers with different amounts of tax bonuses for a dependent child, which reduce the tax base after their application. Each of the analyzed tax legislations allows its taxpayers to claim a tax bonus, for a dependent child included in the wage from the employer monthly or once a year in the tax return (Vasekova and Mateasova, 2017).

In the following Table 4 we will compare the conditions for entitlement to the application of the tax bonus for a dependent child on the basis of the amount of taxable income in the relevant tax period.

Table 4 Conditions of the amount of taxable income in EUR

\begin{tabular}{|c|c|c|c|c|c|}
\hline & $\begin{array}{c}\text { Slovak } \\
\text { republic }\end{array}$ & Czech Republic & Austria & Poland & Hungary \\
\hline $\begin{array}{c}\text { The } \\
\text { amount of } \\
\text { income }\end{array}$ & $>3,738$ & $>3,488.91$ & - & $\begin{array}{c}<24,800.71 / \\
12,400.35\end{array}$ & - \\
\hline
\end{tabular}

Source: Own processing according to the relevant laws on income tax

As we can see in Table 4, the tax legislation of selected states regulates various conditions of the amount of taxable income in the event of entitlement to a tax bonus on a dependent child. The tax legislation of the Slovak and Czech Republic regulates the same conditions of the minimum amount of income when the right to claim the tax bonus arises. The condition for entitlement is the achievement of taxable income in the amount of 6 times the minimum wage. As the minimum wages are set differently in Slovakia and the Czech Republic, the minimum amount of taxable income for entitlement to the tax bonus is also different.

Unlike the Slovak and Czech tax legislation, Polish tax legislation regulates the maximum amount of taxable income upon entitlement to a tax bonus on a dependent child. Tax legislation divides the condition of the maximum amount of taxable income into two categories. Unlike the previous tax legislation, the tax legislation of Austria and Hungary does not regulate the conditions of the amount of income for entitlement to the tax bonus for a dependent child.

In all tax legislation, taxpayers of the relevant state is entitled to the application of the tax bonus. Tax non-residents of selected countries are entitled to the application of the tax bonus if they are caring for a dependent child living with the taxpayer in the same household. In the following Table 5 we recapitulate the amount of the tax bonus for a dependent child, which is provided by the analyzed tax legislation to their taxpayers converted to one month and the ECB exchange rate in the case of foreign currencies. In the case of the Slovak Republic, the data are given with the legislation valid from 1.7.2021.

Table 5 The amount of the monthly tax bonus in the analyzed states in 2021 in EUR

\begin{tabular}{|c|c|c|c|c|c|}
\hline $\begin{array}{c}\text { Number of } \\
\text { kids }\end{array}$ & Slovak republic & $\begin{array}{c}\text { Czech } \\
\text { Republic }\end{array}$ & Austria & Poland & Hungary \\
\hline 1 & $23.22 / 39.47 / 46.44$ & 48.47 & 58.40 & 20.37 & 27.68 \\
\hline 2 & $23.22 / 39.47 / 46.44$ & 61.86 & 58.40 & 20.37 & 55.35 \\
\hline 3 and more & $23.22 / 39.47 / 46.44$ & 77.16 & 58.40 & $36.63 / 49.45$ & 91.33 \\
\hline
\end{tabular}

Source: Own processing based on the analyzed tax legislation

As we can see in Table 5, each tax legislation offers its taxpayers different amounts of tax bonus amounts for a dependent child. In the case of the Slovak Republic and Austria, the tax legislation does not regulate the amount of the tax bonus based on the number of 
dependent children living in the same household as the taxpayer. In Slovakia it depends on the age of the dependent child, while in Austria is the same amount for all the ages.

The tax legislation of the Czech Republic, Poland and Hungary unlike the Slovak Republic, regulates the amounts of the tax bonus based on the number of dependent children living in the same household with the taxpayer.

Based on the results obtained by analyzing the tax legislation of selected countries, we can state that the best tax benefits to its taxpayers from among the selected countries are offered by Austrian tax legislation. We can attribute this to the social policy that Austria has been pursuing recently. Austrian tax legislation is the only one of the selected countries to offer several options for claiming a tax bonus for a dependent child. The disadvantage, in our view, is that Austrian tax legislation distributes the amount of tax bonuses according to the country's standard of living index issued annually by the European Union (Andrejovska, 2019).

After taking into account the country's standard of living, there is discrimination against citizens of countries with a low country's standard of living. In our opinion, the Slovak tax legislation should reconsider the method of calculating the amount of the tax bonus. The current method of calculating the amount of the tax bonus for a dependent child is determined according to the age of the dependent child. In our opinion, this method is not sufficiently motivating to raise more children.

As in other countries, a better alternative is to calculate the amount of the tax bonus according to the number of dependent children living in the same household as the taxpayer. A higher number of dependent children leads to higher household costs, but since the amount of the tax bonus would depend on the number of dependent children, the cost would be at least partially offset by the amount of the tax bonus.

As the population is aging today and the demographic curve is high, according to the Statistical Office of the Slovak Republic, a higher number of dependent children would lead to an improvement in the demographic curve of the Slovak Republic. This would also lead to an improvement in the economy of the Slovak Republic in the future. A higher number of dependent children would create a higher number of labor force in the future, which would lead to an improvement in the GDP of the Slovak Republic and our neighbouring countries (Konecna and Andrejovska, 2020).

\section{Acknowledgement}

This article is an output of the project of the Scientific Grant Agency of the Ministry of Culture of the Slovak Republic and Slovak Academy of Sciences (VEGA) no. 1/0517/20 (2020-2022) "Virtual Cryptochains as a Relevant Tool to Eliminate Economic Crime."

\section{References}

1. Act no. 311/2001 Coll. Labor Code as amended.

2. Act no. 586/1992 Coll. Act of the Czech National Council on Income Taxes.

3. Act no. 595/2003 Coll. on income tax, as amended.

4. Act of July 26, 1991 on personal income tax as amended.

5. Andrejovska, A. (2019). Effective Tax Rate in the Context of the Economic Determinants. Montenegrin Journal of Economics, 15(2), 31-40 .

6. Federal Law of 7 July 1988 on personal income taxation EStG 1988. 
7. Cho, E. (2017). Child benefit portfolios across OECD Countries. Social Indicators research, 132(3), 1099-1115.

8. Jahoda, R., \& Godarova, J. (2012) What we know about the child tax bonus in the Czech repbublic and what we would like to know. 16th International Conference on modern and current trends in the public sector research, Rajecke Teplice, Slovakia, (pp.110-118).

9. Konecna, V., \& Andrejovska, A. (2020). Investor Decision-making in the Context of the Effective Corporate Taxation. E\&M Economics and Management, 23(1), 111-120.

10. Lenartova, G. (2015). Tax systems. Ekonom, Bratislava.

11. OECD (2010). Tax Expenditures in OECD Countries. Paris: OECD Publishing, 2010. http://www.planejamento.gov.br/secretarias/upload/Arquivos/seges/arquivos/ocde2011 /oecd_tax.pdf

12. Paliderova, M., Bielikova, A., \& Spuchlakova, E. (2015). Application of Tax Bonus the Slovak and Czech Republic. 4th world conference on Business, Economics and Management (VCBEM), (pp 404-410).

13. Vasekova, M., \& Mateasova, M. (2017). Analysis of tax burden in the Slovak Republic with emphasis on depreciation. New trends in finance and accounting: proceedings of the 17th annual conference on finance and accounting [ACFA 2016], University of Economics, Prague, Czech Republic.

14. Vostatek, J. (2016). The Fiscalization of child benefits. 21st International Conference on theoretical and practical aspects of public finance 2016, (pp.326-331).

15. 1995. CXVII. law on personal income tax as amended. 